\title{
THE PROBLEM \\ OF THE SEXTA PARTE DE COMEDIAS ESCOGIDAS
}

\author{
Don William Cruickshank \\ Spanish Department \\ University College Dublin \\ National University of Ireland \\ Belfield Campus \\ Dublin 4. Ireland \\ don.cruickshank@ucd.ie
}

[Anuario calderoniano (ISSN: 1888-8046), 3, 2010, pp. 87-113]

The bibliography of the Golden Age is complicated by pirate editions produced by printers trying to evade the cost of obtaining a licence. Even now, these fakes, some of them produced decades after the genuine article, can deceive the unwary. A major publisher has recently produced a CD-ROM which contains the texts of hundreds of classical Spanish plays. This electronic collection is enormously useful to investigators, but at least one of the volumes from which the texts have been scanned is a fake, produced twenty years later than the original.

The size of an edition in the handpress era was often 1200-1500 copies, the number of printed sheets two pressmen could produce in a twelve-hour day. Sometimes editions were half this size, and occasionally they were significantly larger, although the 3000 copies alle- 
gedly produced of Calderón's autos in 1717 was probably the consequence of two separate printing operations. These, relatively, small numbers meant that reprints of popular works were necessary at regular intervals.

As stereotyping was invented only in the eighteenth century, any edition produced before that invention existed only as printed sheets: the type which produced those sheets was back in the cases, because early printers did not have enough material to keep a whole book in standing type. The only way to produce a new edition was to carry out the entire process again, and even when edition A was used as copy, edition B was detectably different. This situation was a godsent opportunity for pirates, who could reprint books and offer them for sale without arousing the suspicions of the buyers or the authorities. It was even possible (since the price of a book depended on the amount of paper used, a quantity often specified in the tasa) to compress the text, saving paper, and continue to sell the book at the original price.

When it came to plays, Golden-Age pirates had another advantage. The practice of selling novels in serial parts had still to be invented, but the earliest editions of single plays, comedias sueltas, go back to the first decade of the sixteenth century. In the 1560s, Juan de Timoneda, who wrote plays as well as printed them, hit on the idea of the desglosable, a printed play designed as part of a volume, sometimes with appropriate pagination, but which was self-contained in binding terms, so that it could be sold separately without splitting a gathering ${ }^{1}$.

The trade in sueltas was huge. Efforts to calculate the number of editions produced in this format have produced over 1600 titles, some of them printed in dozens of editions. An inventory made in 1720 shows that a printer in Seville had over 210.000 sueltas in his stock ${ }^{2}$. These figures, and the precedent of the desglosable, meant that the pirate who wanted to produce a parte of twelve plays had no need to

${ }^{1} \mathrm{I}$ am thinking of his Turiana, Valencia, 1564-1565. The one surviving copy is imperfect, but we can deduce that its collation was $\mathrm{A}^{2}$ (prelims) $\mathrm{B}^{8} \mathrm{C}^{12} \mathrm{D}^{10} \mathrm{E}^{12}\left[\mathrm{~F}^{\text {? }}\right.$ $\left.\mathrm{G}^{3}\right] \mathrm{H}^{10}$. Plays did not run across gatherings: the size of the gathering was governed by the length of the play it contained, and each one was a potentially separate unit.

2 The total was 17.571 dozen: see Bergman, 1983, pp. 126-127). 
print any: all he needed to print was the preliminaries. The only adjustment he needed to make to these was the omission of page-numbers in the tabla. Since his collection had no continuous pagination, the inclusion of such numbers would only draw attention to his fraud.

The largest fraud of this kind apparently involved the Vera Tassis edition of Calderón's plays: nine volumes, 108 plays, originally produced between 1682 and 1691. The whole collection was reproduced using sueltas, probably soon after 1700 . As well as creating a bibliographical hazard, these pirates also created a ghost: by mistakenly putting the date 1683 on the fake reprinted title-page of the Segunda parte (instead of 1686), they caused even scholars who identified the fake for what it was to assume the existence of a "genuine» 1683 edition on which it must have been based.

Sometimes, however, evidence seems to force us to conclude that a book which no modern bibliographer has handled did once exist. Such a one is Part VI of the Comedias escogidas series. When La Barrera listed the Sexta parte in his Catálogo in 1860, he said it was very rare, and admitted that he had never seen a copy. He described one of Madrid 1654 supposedly seen by von Schack, and referred to two editions produced in Zaragoza by the Heirs of Pedro Lanaja, with different contents, dated 1653 and 1654 . He did not say where the copies were, only that the Madrid edition was not held by the National Library in Madrid or the Imperial Library in Vienna. He suggested that the volume's rarity might be due to the prohibition of one of the plays, El pleito del demonio con la virgen, attributed to tres ingenios ${ }^{3}$.

The term parte de comedias seems to originate in Seville with Juan de la Cueva, whose Primera parte was published in $1588^{4}$. In 1603 there appeared a volume, ostensibly produced in Lisbon by Pedro Craesbeeck, with the title Seis comedias de Lope de Vega Carpio y de otros autores. The reference to "other authors» concealed the fact that only two of the plays were by Lope. Lope condemned the publication:

Ahora han salido algunas comedias que, impresas en Castilla, dicen que en Lisboa [...]; no crean que aquéllas son mis comedias, aunque tengan mi nombre;

3 See Barrera y Leirado, 1860, p. 689.

${ }^{4}$ Primera parte de las comedias y tragedias, Sevilla, Juan de León, 1588.

${ }^{5}$ Lope de Vega, El peregrino en su patria, ed. Avalle-Arce, 1973, p. 57. 
but the book trade had made an important new discovery, although the booksellers did not act on it immediately: if they had too few plays by a single author to fill a volume, they could publish a collection of plays by "different authors», without advertising the fact that most of the volume was not by a best-selling playwright. In due course there began the series usually known as Diferentes, probably soon after the publication of Lope's Parte veinte (1625). It has been suggested that a volume with no title-page preserved in Freiburg may be the first, with the hypothetical title Parte veintiuna de Lope y otros autores ${ }^{6}$. The series ended in 1652 with Parte quarenta y quatro de comedias de diferentes autores (Zaragoza, Heirs of Pedro Lanaja). Most of the volumes were produced, at least ostensibly, in the kingdom of Aragón: Zaragoza, Huesca, Valencia, Barcelona. It should be remembered that in the ten years from 1625 to 1634 the Council of Castile refused to issue licences for printing plays?.

Whether or not they realised that Parte cuarenta y cuatro was the last of its series, the booksellers of Madrid decided that they were missing an opportunity. In that year (1652) they produced the Primera parte de comedias escogidas de los mejores ingenios de España (Madrid, Domingo García y Morrás, for Juan de San Vicente) and the Segunda parte de comedias escogidas de las mejores de España (Madrid, Imprenta Real, for Antonio Ribero). Not all of the collective titles used the words "comedias escogidas", but this came to be the name of the series, which lasted until the appearance of Escogidas cuarenta $y$ ocho in 1704 , at an average of almost one volume per year ${ }^{8}$.

In 1653 the series continued with volumes III (Melchor Sánchez, for José Muñoz Barma), IV (Imprenta Real, for Diego de Balbuena) and V (Pablo de Val, for Juan de San Vicente). Part VI should have been produced in either 1653 or 1654, but something went wrong, as La Barrera noticed. The problem was not that there was no Sexta parte: the problem was that there were several. La Barrera implied that the original volume, published in 1653 or 1654, and suppressed because of El pleito del demonio con la virgen, was «reconstructed» subsequently. His wording could be taken to mean that he thought that there were

\footnotetext{
6 See Profeti, 1988, pp. 21-27.

7 See Moll, 1974.

${ }^{8}$ See Cotarelo y Mori, 1931 y 1932.
} 
several attempts at reconstruction, but he never said so. Given the lack in 1860 of the electronic and photographic aids which we now take for granted, he had no easy way of finding and comparing the different copies. Nor did he explain how it was that the list of titles provided by von Schack included El pleito del demonio, despite the prohibition, although perhaps the implication was that prohibition took place after distribution had begun, allowing at least von Schack's copy to escape. The play exists both in manuscript and in sueltas, and although I have not compared all the versions, there seems to be no obvious reason why it should have been prohibited.

Since La Barrera, various scholars have acknowledged the existence of the Sexta parte problem, especially the fact that different copies vary. Over thirty years ago Maria Grazia Profeti recorded and partially described the known copies. Unfortunately, her useful article is not easily available, and its descriptions are not sufficiently detailed to distinguish fully the different suelta editions, or to date them ${ }^{9}$. This paper tries to make some guesses about where and when the sueltas were produced, as well as the place and date of assembly of the volumes. So far, there appear to be eight surviving volumes which claim to be the Sexta parte. There are two in the Österreichische Nationalbibliothek, and one each in the Biblioteca Nacional, the British Library, the Biblioteca Nazionale, Florence, the Bodleian Library, Boston Public Library and the Universitätsbibliothek Freiburg. The copy formerly held in the Berlin Staatsbibliothek is $\operatorname{lost}^{10}$. Profeti saw seven of the copies, that is, all except those in Berlin and Boston.

As just noted, the Biblioteca Nacional possesses one of the copies. The title-page is missing, and a handwritten leaf proclaims that this is the Parte sexta de comedias varias de diferentes autores. Con Licencia. Año de 1649. A contents-leaf has survived, with no page-numbers (a tacit admission that the volume is composed of sueltas), and no authors' names, although names have been added in a nineteenth-century hand to ten of the titles. I supply a transcription, and also add collations:

9 Profeti, 1976-1978.

10 The Berlin Staatsbibliothek copy had the pressmark Xk.1728, but the library tells me that this copy disappeared during the Second World War. 
1 No ay ser padre siendo rey (de Roxas) [4 ${ }^{0}$. A-D ${ }^{4}$. 16 leaves, unnumbered]

2 Cada qual à su negocio (de Geronimo de Cuellar) [4 ${ }^{0} . \mathrm{A}-\mathrm{D}^{4} .16$ leaves, unnumbered]

3 El burlador de Seuilla (de Tirso de Molina) $\left[4^{0}\right.$. A-D E $^{2} .18$ leaves, unnumbered]

4 Prone [sic] y Filomena (de Roxas) $\left[4^{0} . \mathrm{A}-\mathrm{E}^{4}\left[\mathrm{~F}^{2}\right]\right.$ (C2 mis-signed CS, last gathering unsigned). 22 folios, 19 apparently misnumbered 16]

5 Obligados y ofendidos (de Roxas) [4 $4^{0} . \mathrm{A}-\mathrm{D}^{4} \mathrm{E}^{2} .18$ leaves, unnumbered]

6 El esclauo del demonio (de Mira de Amescua) $\left[4^{0}\right.$. A-B ${ }^{8} C^{6}$ (A1 unsigned?). 44 pages (1 unnumbered, 27 misnumbered 24, 36 and 37 misnumbered 38 and 39); last 4 pages printed in smaller type, ca. $74 \mathrm{~mm} / 20$ lines]

$7 \mathrm{El}$ pleito del demonio con la virgen [by tres ingenios in text, but possibly by Rojas, according to MacCurdy $]^{11}\left[4^{0}\right.$. A-E .20 leaves, unnumbered]

8 Los trabajos de Iob (de Felipe Godinez) $\left[4^{0}\right.$. A-D ${ }^{4}$. 16 leaves, unnumbered]

9 La banda y la flor (de Calderon) $\left[4^{0}\right.$. A-E $\mathrm{E}^{4} .20$ leaves, unnumbered; E1 missigned $\mathrm{F}$ ]

10 A vn tiempo rey y vasallo [unattributed, but by tres ingenios: Cáncer, Antonio de Vargas, Belmonte Bermúdez?] [4‥ A-D ${ }^{4}$. Paginated, 1-29 [30-32]

11 Los Medicis de Florencia (de Ximenez de Enciso) [4 $4^{0}$. A-F .24 leaves, unnumbered]

12 El principe constante (de Calderon) [4 $4^{0}$. A-E $\mathrm{E}^{4} .20$ leaves, unnumbered].

With the exception of number 6, El esclavo del demonio, all of these are quartos in fours, but while most have no numbering on the leaves, number 4 is foliated and numbers 6 and 10 are paginated. At first sight, they seem to be the work of several printers. Like most seventeenth-century sueltas, they have no imprints, but number 10 , which is printed on noticeably better paper than the others, has a woodblock tailpiece of $85 \times 98 \mathrm{~mm}^{12}$. This block belonged to Tomé de Dios Miranda of Seville, who used it on several occasions between 1675 and 1678 as a suelta tailpiece. Woodblocks can be lent, and Miranda was active between 1666 and 1678, but the suelta is printed in types used by him in the mid 1670s: he probably produced it around $1675^{13}$. Seven of the other sueltas show another typographical featu-

11 See MacCurdy, 1965, p. 10.

12 Illustrated in Wilson and Cruickshank, 1980, p. 84.

13 See Wilson and Cruickshank, 1980, in particular R34 (pp. 47, 75), and IT13C (pp. 52, 79), the two text-types. 
re: a two-dot $\mathrm{j}$, almost always found in the gros cicéro of Robert Granjon, although occasionally it gets mixed with other pica roman designs (nos. 2, 4, 5, 6, 7, 11,12) ${ }^{14}$. Granjon did not cut this $\mathrm{j}$ : it is found almost exclusively in the work of Madrid printers between 1664 and 1676. Those sueltas which have very few examples are likely to date from the end of this period.

The British Library copy is the same as the Madrid one throughout, except for a different edition of Obligados y ofendidos (num. 5), and for the surviving title-page (PARTE SEXTA. | DE | COMEDIAS | DE LOS MEjORES | INGENIOS DE ESPAÑA. | [woodblock, sheaf of flowers] | CON LICENCIA. | [line in 13 pieces] | EN MADRID.). Signora Profeti described the Madrid and London copies as the same, but she had not noticed the slightly variant print of Obligados. She also noted that the title-page woodblock of the London copy was used by Julián de Paredes in 1675 in Escogidas XL, but this is not correct. The two blocks are so nearly identical that one was clearly copied from the other. They are contemporary to that extent at least, but they are two different blocks, and we cannot assume that Paredes owned both of them. The block of the London copy of the Sexta parte is found elsewhere, however: the Universitätsbibliothek Göttingen has a Parte primera de comedias de los mejores ingenios de España in which the title-page not only has the same block, but also uses the same standing type (with PRIMERA substituted for SEXTA) as that of the London Sexta parte ${ }^{15}$. This volume purports to be a copy of Escogidas I, but no date or printer's name appear on the title-page. However, the tabla, which is typographically quite different from that of the London Sexta parte, lists the correct plays for Escogidas I, with the correct folio numbers ${ }^{16}$. One explanation is that the assembler of the London Sexta parte obtained a copy of Escogidas I which lacked the title-page, and produced one to make the volume marketable, at the same time as the London parte's title-page was being printed.

${ }^{14}$ For the j, see Wilson and Cruickshank, 1980, pp. 46, 75. The cicéro was first used around 1568, and first fully illustrated in the Fuhrmann specimen of 1616: see Dreyfus, 1963-1972, t. I, 4 (hereafter TSF).

$158^{0}$ Poet. Dram. II 49 Vol. I.

16 Escogidas $I$ is another parte which needs to be investigated, since surviving copies differ. 
The Boston copy contains the same plays as the Madrid and London copies, in the same order, although the edition of Calderón's La banda y la flor varies. All three copies have a contents-page in the same setting of type, with the heading "COMEDIAS QVE TIENE | este tomo sexto"; attributions have been added by hand, but the handwriting differs from that of the Madrid copy. Strangely, the title-page of the Boston copy is quite different from that of London: COMEDIAS | NVEVAS | ESCOGIDAS DE LOS | MEjORES INGENIOS DE ESPAñA. | PARTE SEXTA. | [basket of flowers] | - | CON LICENCIA. En Madrid. | The title-page has a border composed of 84 metal ornaments, all but two of them arranged in pairs, and while the basket of flowers closely resembles that on the titlepage of Los trabajos de Persiles y Sigismunda (Madrid, Juan de la Cuesta, 1617), it is different.

The only two-dot $\mathrm{j}$ sueltas I can attribute so far in the Madrid / London / Boston volumes are numbers 7 and 11, both of which use three different queries in their text-type, but not the same three. None of these sorts, on its own, is unique, but each combination was used by only one printer, round about 1675: Bernardo de Hervada (Madrid: number 7) and Lucas Antonio de Bedmar (Madrid: number 11). Number 3, El burlador de Sevilla, is also by Bedmar, but a couple of years earlier, when his stock of type was different. As for the edition of Obligados y ofendidos found in the London copy, it is contemporary with number 11, printed by Bedmar about 1675 . The date on the handwritten title-page of the Madrid copy, 1649, is clearly wrong; the London and Boston copies, perhaps trying to be honest (but perhaps not), give no date or printer, merely a place, Madrid. The evidence points to assembly in the period 1675-1680, possibly in Madrid, although not all of the volume's contents had been printed there.

Since these editions are true sueltas, one would expect to find examples of them elsewhere, bound alone, or in other suelta collections. I have been able to check that the London Library's P.997-4 is another copy of Calderón's La banda y la flor (num. 9, Madrid and London copies); and while I have not examined them, the same library also appears to have copies of num. 2, Cada cual a su negocio, and 6, Obligados y ofendidos; and although the published descriptions do not quite match, the library's copies of nos. 1 (No hay ser padre siendo 
rey) and 10 ( $A$ un tiempo rey y vasallo) are evidently of the same, or very similar, editions ${ }^{17}$.

In ostensible chronological order, the next Sexta parte is the one supposedly produced in Zaragoza by the heirs of Pedro Lanaja $y$ Lamarca in 1653 (Plate 1). The heirs of Pedro Lanaja were active from 1649 onwards, but the types of the preliminaries are too common to say for certain that they printed them. There appears to be only one surviving copy of this version, in Vienna: it can be referred to as Vienna 1. The tabla gives these details:

1 Mirad à quien alabais. De Lope de Vega Carpio. $\left[4^{0}\right.$. A-D ${ }^{4}, \mathrm{~A} 3$ signed. 16 leaves, unnumbered]

2 El Angel de la guarda. De D. Pedro Calderón. [not authentic; $4^{0}$. A-D ${ }^{4}$, all leaves signed save A4. 16 leaves, unnumbered]

3 El Capitan Belisario. De Lope de Vega. [i.e., Mira de Amescua; $4^{0}$. A-D ${ }^{4}$, all leaves signed save D3, D4. 16 leaves, unnumbered]

4 El diablo predicador. De Luis de Velmõte. $\left[4^{0}\right.$. A- ${ }^{4}$, first three leaves of each gathering signed. 16 leaves, unnumbered]

5 Los Principes de la Iglesia. De D. Christoual de Monroy. [4 ${ }^{0}$. A-D ${ }^{4} .16$ leaves, unnumbered]

6 Dineros son calidad. De Lope de Vega. [doubtful; $4^{0}$. A-D ${ }^{4} .16$ leaves, unnumbered]

7 El juramento ante Dios. De Iacinto Cordero. [4 ${ }^{0}$. A-D ${ }^{4} .16$ leaves, unnumbered]

8 Las mocedades de Bernardo del Carpio. De Lope de Vega. [4 ${ }^{0}$. A-D ${ }^{4} .16$ leaves, unnumbered]

9 Los Encantos de Medea. De Roxas. [4 $4^{0}$. A-C $\mathrm{C}^{4} \mathrm{D}^{2} .14$ leaves, unnumbered]

10 El satisfazer callãdo, y Princesa de los Mõtes. De Lope de Vega. [4 ${ }^{0}$. A-D ${ }^{4}$, A1 unsigned. 16 leaves, unnumbered]

11 Don Domingo de Don Blas. De Iuan Ruiz de Alarcon. [4 $4^{\circ}$ A-D ${ }^{4}$, all leaves signed. 16 leaves, unnumbered]

12 Vengarse con fuego, $y$ agua. De Don Pedro Calderon. $\left[4^{0}\right.$. A-D ${ }^{4}$, first three leaves of each gathering signed. 16 leaves, unnumbered].

This volume has completely different contents from the Madrid / London / Boston version. The last play is really Calderón's $A$ secreto

17 See Gregg, 1984, nums. 19, 162, 212, 1024, 1061. 
agravio, secreta venganza, while El capitán Belisario includes the entremés El médico del tabaco at the end as a filler.

What is extraordinary about this collection is that all the sueltas it contains collate A- $\mathrm{D}^{4}$, with the exception of Los encantos de Medea, which is actually too short for four complete quarto gatherings. This is so convenient as to be very suspicious, especially since three of the plays end neatly at the foot of the last page. A line-count of one of them, Vengarse con fuego y agua, finds 2564. A count of $A$ secreto agravio in Calderón's Segunda parte (1637, QC) gives 2748: the suelta text has been compressed, saving ten pages of the Segunda parte's forty-two, but neatness has been achieved at the cost of 184 lines. With the aid of a little arithmetic, we can understand more clearly what was taking place. Arithmetic was crucial to seventeenth-century compositors. Too short of type to set pages seriatim, they had to cast off (count) their text to set it by formes. Four quarto gatherings (sixteen leaves) is thirty-two pages. At two columns per page and forty-two lines per column, they knew they had room for a total of 2688 lines of text, but the heading, list of characters, act-titles, stage directions, the splitting of lines with different speakers, would together reduce this theoretical maximum to less than 2600. A play with 2748 lines was simply too long. When he compiled his printer's manual in 1680, Alonso Víctor de Paredes referred to the problem of counting the text, and to the solutions which could be adopted when the count was too long or too short:

como no son Angeles los que cuentan, es fuerça que vna, o otra vez salga la cuenta larga o corta; y aviendo de remediarse la larga con tildes [e.g., dõde] y la corta con espacios (si ya no se valen de otros medios feos, y no permitidos, que no los expecifico porque se olviden si es possible) queda lo impresso con notable fealdad ${ }^{18}$.

Eight years earlier, Calderón had referred less coyly to the methods alluded to: «donde acaba el pliego, acaba la Iornada, y donde acaba el quaderno, acaba la Comedia» ${ }^{19}$. Francisco Rico has amassed some de-

18 Alonso Víctor de Paredes, Institución y origen del arte de la imprenta (Madrid, 1680), ed. Moll, 1984, fol. 35v.

${ }^{19}$ Calderón de la Barca, Quarta parte de comedias, Madrid, Joseph Fernández de Buendía, 1672), $₫ \llbracket 2$. 
vastating evidence to show how frequently counting errors were resolved by textual padding or omissions ${ }^{20}$.

There are other noteworthy features about these twelve sueltas. By the middle of the seventeenth century, compositors normally put signatures on the first half of the pages in a gathering: in a quarto in fours, A on leaf 1 and A2 on leaf 2; the third and fourth leaves were not signed. This happens in only seven of the twelve, while the other five sign three or four of the leaves in a gathering. This practice was common in the first half of the century. It is clear, too, that although the same type designs are not always used for the same purpose in all twelve, all the sueltas show signs of having been produced in the same printing-house. This is true in particular of the text roman and italic, which are the same in all of them. If the printer of Vengarse con fuego $y$ agua can be identified, then it is probably safe to conclude that he printed the others (Plate 2).

The roman faces visible in Vengarse are common enough, but the three italic faces are more helpful. The tiny one is Granjon's cicéro cursive, which goes back to $1548^{21}$. The only printers still using it in Spain after 1620 seem to have been in Seville. The design used for the author's name is Granjon's gros texte italique, series 3, which Plantin had by $1564^{22}$. It is noticeable that the $R$ of PEDRO is different from the $R$ of CALDERON. This is not a swash variety of the same face, like the $D$ of $D E$ : this is a different face, François Guyot's texte italique 23 . Guyot's texte may be the commonest italic used in Spain, but relatively few printers mixed it with Granjon texte; one who did was Simón Faxardo of Seville, who also had the small Granjon cicéro. While the date needs more research, it looks like late 1630s, early 1640s. Faxardo apparently died at the time of the Seville plague in 1650: he cannot have assembled this volume, but he is the most likely printer of the sueltas of which it is composed. The person who put the volume together was willing to use editions which were at least a decade old, and which he had not printed. He is not likely to have worried

\footnotetext{
${ }^{20}$ Rico, 2005, Chapter II, "Cómo se hacía un libro en el Siglo de Oro», pp. 53-

21 See Cruickshank, 2004, pp. 973-1010 (998-999, 1007).

22 Cruickshank, 2004, pp. 987-988, 1006.

23 Cruickshank, 2004, pp. 982-986, 1005.
} 93. 
about the textual reliability of the editions he used, but the message to editors is clear: being early need not make a suelta text reliable.

While the sueltas in this volume are undoubtedly rare, the Catálogo colectivo has tentatively identified separately-bound copies of two of them in the Biblioteca del Palacio Real: Lope's Las mocedades de Bernardo del Carpio (VIII/17140(9)) and Monroy's Los príncipes de la iglesia (VIII/17144(2)). The collations correspond, although I have not been able to examine them. Many years ago Eduardo Juliá suggested that an edition of El ángel de la guarda, attributed to Calderón and preserved in the Biblioteca Provincial, Toledo, was another copy of the suelta in Vienna 1, but it is perhaps worth noting that while the Catálogo colectivo lists this copy, it no longer links it with the Sexta parte ${ }^{24}$.

Printing standards in seventeenth-century Spain were low. Printers used worn, damaged and adulterated type, which is helpful; but the low standards also mean that careless inking on poor paper partly cancels out this source of information. To overcome this problem, one can use multiple copies, which permits the identification of damaged sorts in type as small as pica (12-point). In the case of the 1654 version of the Sexta parte, there are also three copies available for examination:Vienna 2, Bodley and Florence (Plate 3). The contents are as follows:

1 No ay ser padre siendo rey. De don Francisco de Roxas. [4 $4^{0}$. A-E ${ }^{4}$; third leaf in each gathering signed. 20 leaves, unnumbered]

2 Cada qual à su negocio. De don Geronimo de Cuellar. $\left[4^{0} . \mathrm{A}-\mathrm{B}^{8} \mathrm{C}^{6} .22\right.$ leaves, unnumbered]

3 El Burlador de Seuilla. Del Maestro Tirso de Molina. [4 ${ }^{0}$. A-D ${ }^{4} .16$ leaves, unnumbered]

4 Progne y Filomena. De don Francisco de Roxas. $\left[4^{0} . \mathrm{A}^{-\mathrm{B}^{8}} \mathrm{C}^{6}\right] .22$ leaves, unnumbered]

5 Los Trabajos de Iob. Del Doctor Felipe Godinez. [4․ A-B ${ }^{8} .16$ leaves, unnumbered]

6 Obligados y ofendidos. De don Francisco de Roxas. $\left[4^{0} . \mathrm{A}-\mathrm{B}^{8} \mathrm{C}^{6} .22\right.$ leaves, unnumbered]

24 Juliá Martínez, 1932 y 1933. The holdings of the Biblioteca Provincial now form part of the Biblioteca de Castilla-La Mancha, and this suelta, with the pressmark $1-862(1)$, has the same collation $\left(\mathrm{A}-\mathrm{D}^{4}\right)$ as that in Vienna 1 , but it may or may not be of the same edition. 
7 El esclauo del demonio. Del Doctor Mirademescua. $\left[4^{0}\right.$. A-D ${ }^{4} E^{2} .18$ leaves, unnumbered]

8 El martir de Portugal [= El príncipe constante]. De don Pedro Calderon. $\left[4^{0} . \mathrm{A}-\mathrm{D}^{4} \mathrm{E}^{2} .18\right.$ leaves, unnumbered]

9 La Vanda y la flor. De don Pedro Calderon. [4 $4^{0}$. A-D ${ }^{4} E^{2} .18$ leaves, unnumbered]

10 A vn tiempo rey y vasallo. De tres Ingenios. $\left[4^{0}\right.$. A-D ${ }^{4} .16$ leaves, unnumbered (play ends D3r, followed by poem, "Pintura a una dama», by Cáncer; woodblock on D4v)]

$11 \mathrm{El}$ pleito del demonio con la virgen. De tres Ingenios. $\left[4^{0}\right.$. A- $\mathrm{B}^{8} \mathrm{C}^{2}(\mathrm{C} 1$ signed E). 18 leaves, unnumbered]

12 El gran Duque de Florencia [= Los Medicis de Florencia, the title used in the suelta]. De don Diego Ximenez de Enciso. [4 ${ }^{\circ}$. A-C ${ }^{8}$; C8 blank. 24 leaves, unnumbered]

One of the damaged sorts referred to above is in Granjon's capitales sur deux lignes de cicéro, in which an $\mathrm{O}$ recurs in numbers 1, 4 and 6 (Plate 4); another is an E in the same design, recurring in 3 and 5 $(\text { Plate } 5)^{25}$. These are not examples of standing type, as can be discovered from other sorts and by measurement: they are merely damaged sorts which happen to be used again in the same place. However, together with style and the use of other designs, they help to suggest that this volume is made up of two groups of sueltas. Number 10, with its woodblock tailpiece (Plate 6), is in the second group. This block belonged to the Imprenta Real of Madrid, which used it in the 1654 edition of Góngora's Todas las obras (146v). This table lists the two groups:

Group 1

No hay ser padre siendo rey (play 1)

Progne y Filomena (4)

Obligados y ofendidos (6)

El mártir de Portugal (8)

Los Médicis de Florencia (12)
Group 2

Cada cual a su negocio (2)

El burlador de Sevilla (3)

Los trabajos de Job (5)

El esclavo del demonio (7)

La banda y la flor (9)

A un tiempo rey y vasallo (10)

[+ woodblock

El pleito del demonio

[con la virgen (11)

25 Shown in Plantin's Index characterorum of 1567. See TSF, t. II, p. 2, n. 2. 
Half of the sueltas are quarto in fours, half quarto in eights, apparently in a random fashion. Group 1 gives authors' names in italics, usually in Guyot texte, while Group 2 has them in roman. In fact, Group 1 is remarkably homogeneous: all the plays in this group use the same four roman designs and the same two italics. This looks like the work of one compositor over a short period. The second group is more mixed, but all seven plays use the same pica roman and italic in their texts. Of a total of eleven designs, five are found in both groups. The second group is the one which has the Imprenta Real woodblock. The same group also has a very rare design, used once, in suelta 2: the $: 5.5 \mathrm{~mm}$ titling capitals attributed to Claude Garamont ${ }^{26}$. Apparently only one firm was using these in Spain in the mid seventeenth century: the Imprenta Real, between 1637 and 1660. This information prompts a more thorough examination of the designs used in the two groups, which may be tabulated as follows:

Group 1 types:

Granjon capitales sur deux lignes de cicéro

Granjon ascendonica romaine ${ }^{27}$

Garamont texte romain ${ }^{28}$

Granjon gros cicéro

Guyot texte italique

Granjon italicque St Augustin seconde ${ }^{29}$
Sueltas

$$
\begin{aligned}
& 1,4,6,8,12 \\
& 1,4,6,8,12 \\
& 1,4,6,8,12 \\
& 1,4,6,8,12 \\
& 1,4,6,8,12 \\
& 1,4,6,8,12
\end{aligned}
$$

Group 2 types:

Granjon capitales sur deux lignes de cicéro Granjon petit canon romain ${ }^{30}$ $2,3,5,7,10,11$

Garamont (attrib.) :5.5mm caps

$2,3,5,9,11$

Granjon ascendonica romaine

2

Granjon parangon romain ${ }^{31}$ 
Garamont texte romain

Granjon gros cicéro, mixed with Berton ${ }^{32}$

Guyot texte italique

Granjon médiane cursive pendante (copy) $)^{33}$
$5,7,9$

$2,3,5,7,9,10,11$

9

$2,3,5,7,9,10,11$

Use of these types in Góngora, Todas las obras (Madrid, Imprenta Real, 1654):

Granjon capitales sur deux lignes de cicéro

Granjon petit canon romain

Garamont :5.5mm caps

Granjon ascendonica romaine

Granjon parangon romain

Garamont texte romain

Granjon gros cicéro on its own

Granjon gros cicéro, mixed with Berton

Guyot texte italique

Granjon St Augustin italicque seconde

Granjon médiane cursive pendante (copy)

The evidence seems quite conclusive: all twelve sueltas were produced by the Imprenta Real, probably close to 1654. Group 2 may be of a slightly different date from Group 1, and is probably by a different compositor. While there is a lack of standing type in headings, there is one curious piece of evidence: in two plays of group 2, $A$ un tiempo rey $y$ vasallo and El pleito del demonio, the title of Act II is set as IORNANA SEGVNDA. The odds are against this quaint mistake being made twice, and it would be normal for a compositor to tie a string round the type of an act-heading to keep for the next play.

Who, it may be asked, assembled this volume? Variants of the griffin woodblock used on the title-page have been recorded in Córdoba, Bilbao, Valladolid and Valencia ${ }^{34}$. Restori believed that a block used by Juan Gracián of Alcalá in the 1570s was the same, but it is not: so far there is no evidence that the Sexta parte griffin was ever used in any

32 For Barthélemy Berton's pica roman, see Wilson and Cruickshank, 1980, pp. 47, 75 .

33 See Cruickshank, 2004, pp. 1000-1001, 1007.

${ }^{34}$ Vindel, 1942, nums. 272, 304, 320, 342, 356, 380, 467, 472, 485. 
other book ${ }^{35}$. The type offers better evidence. Apart from the $: 13 \mathrm{~mm}$ Vatican Foundry capitals, the preliminaries use all the same designs as the sueltas; and of course the Imprenta Real also had those ${ }^{36}$.

More research remains to be done, but a hypothetical explanation for what happened is possible. In 1653, Pablo de Val of Madrid produced Escogidas $V$. In Zaragoza, the Heirs of Pedro Lanaja, who had produced Diferentes XLIV in 1652, decided to jump on the bandwagon of the Madrid printers who had jumped on theirs: they produced the Escogidas VI volume which carries the date 1653. They used ready-printed sueltas, either because they were in a hurry, and/or because this was their practice: their Diferentes XLIV is composed of sueltas. The imprint and date used were genuine. The Imprenta Real, which had produced Escogidas IV in 1653, may have been planning Escogidas VI, but they reacted quickly to the news from Zaragoza. They took twelve sueltas which they had recently printed for sale as sueltas, all of them different from those in the Zaragoza volume, and bound them up with a set of preliminaries in which, to make a point, they put the name of the interlopers, this time adding that of the publisher Roberto Duport. The name of Duport, or De Uport, is not common, but he published books as early as 1627 and as late as 1660: he was in business in 1654 .

There is a possible variant in this hypothesis: someone in Madrid, possibly the Imprenta Real, may have produced an Escogidas VI as a "proper book», only to see it suppressed. The news of this possible suppression may have encouraged the Lanaja Heirs to produce an alternative version, whereupon the Imprenta Real assembled their version, which may or may not have been the same as the suppressed one. They sidestepped the usual slow licensing process, pretending that the volume had been produced in the kingdom of Aragon. Either they were simply in a hurry, or they were issuing something which had been banned in Castile.

If a printer produces a fake volume from existing sueltas, there are likely to be fewer copies, especially if he uses the remains of stocks which have been on sale for over ten years. That might account for

35 Restori, 1927, p. 33 n. 2, quoting Juan Catalina García, Ensayo de una tipografía complutense, Madrid, Manuel Tello, 1889, p. 622.

${ }^{36}$ Vervliet, 1967, item 27; very common in Spain. 
the unique surviving copy of the 1653 version, and for the larger number of copies of the 1654 version, which used more recent sueltas. Within twenty years, there were no copies to be had of either, so the obliging book trade made some more, basing them on the 1654 version, represented by the Vienna 2/Bodley/Florence copies. That is, in the late 1670s, someone in Madrid assembled the British Library / Biblioteca Nacional / Boston version. The assembler got the right plays, but he put them in a slightly different order. In two cases he got the same play under a different title, and for two plays he used two editions, but all of the editions were different from those of 1654 . The preliminaries were entirely reprinted. As for the copy now in Freiburg, it too is different. The assemblers took the preliminaries from a copy of Escogidas VII, which also happened to have the date they wanted, 1654, and simply rubbed out references to «seven" where they occurred. On the title-page proper, the words PARTE SEYS were written by hand in a style that a very short-sighted reader might mistake for type. They had to print a new contents-leaf, but although they found all the right plays, one had a different alternative title, and they used yet another order. Some of the editions are the same as those in the Madrid / London / Boston copies, but others are different. One in particular, of Obligados y ofendidos, has an imprint: the Heirs of Juan Sanz of Madrid, which puts it in the 1720s. If this particular copy was originally assembled in its current form, it was put together much later than the others, although some of the editions used were sixty years old.

In conclusion, there is as yet no convincing evidence that there ever was a «normal» Sexta parte produced in Madrid in either 1653 or 1654. The description La Barrera takes from von Schack gives the order and titles of plays exactly as in the Vienna 2 / Bodley / Florence version. It seems at least as likely that von Schack simply gave the wrong place as it is that he had somehow got his hands on a copy of the «real» Madrid 1654 edition (which, of course, has now vanished). Ockham's razor is as useful a maxim for bibliographers as it is for anyone else $^{37}$.

37 I am very grateful to Professor Luis Iglesias Feijoo of the Universidade de Santiago for his help in obtaining copies of the different versions of the Sexta parte. 
The four versions of Escogidas VI

1 Escogidas VI, «1649» [ca. 1675-80]: Madrid, R/22659; London, 11725.b.6; Boston, D.172.1.6.

No ay ser padre siendo rey (uncertain).

Cada qual à su negocio (occasional 2-dot j, e.g., B2v; Madrid?, ca. 1676).

El burlador de Seuilla (Lucas Antonio de Bedmar, Madrid, ca. 1673).

Progne y Filomena (2-dot j throughout; Madrid?, ca. 1664-1676).

Obligados y ofendidos ([London copy] occasional 2-dot j: Lucas Antonio de Bedmar, Madrid, ca. 1673).

El esclauo del demonio (2-dot j on A2r, although text-type is Haultin, not Granjon; Madrid?, ca. 1676).

El pleito del demonio con la virgen (2-dot $\mathrm{j}$ throughout; Bernardo de Hervada, Madrid, ca. 1675).

Los trabajos de Iob (uncertain).

La banda y la flor (uncertain).

A vn tiempo rey y vasallo (Tomé de Dios Miranda, Seville, ca. 1675-1678)

Los Medicis de Florencia (occasional 2-dot j, e.g., F3v; Lucas Antonio de Bedmar, Madrid, ca. 1676).

El principe constante (2-dot j on B4v; Madrid?, ca. 1676).

2 Escogidas VI, «1653»:Vienna 1, ^38.V.10(6): all twelve plays apparently printed by Simón Faxardo, Seville, ca. 1635-1645.

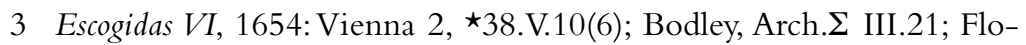
rence, 11-6-103-VI: all twelve plays printed by Imprenta Real, Madrid, ca. 1654.

4 Escogidas VI, «1654», Freiburg, E 1032, k-6.

No ay ser padre siendo rey (as in version 1; Stark, num. 872) ) $^{38}$.

El burlador de Sevilla (as in version 1; Stark, num. 160).

Progne y Filomena (as in version 1; Stark, num. 1032).

Obligados y ofendidos (Madrid, heirs of Juan Sanz; Stark, num. 898).

La banda y la flor (2-dot j, but differs from version 1; Stark, num. 131).

El pleito del demonio con la virgen (2-dot j, but differs from version 1; Stark, num. 979).

El esclavo del demonio (as in version 1; Stark, num. 461).

Los trabajos de Job (as in version 1; Stark, num. 1199).

El príncipe constante (differs from version 1; Stark, num. 1019).

38 References are to Stark, 2003. 
Los Médicis de Florencia (as in version 1; Stark, num. 771).

A un tiempo rey y vasallo (2-dot j, but differs from version 1; Stark, num. 11).

Cada qual a su negocio (differs from version 1; Stark, num. 174). 


\section{BibLIOGRAPHY}

Barrera y Leirado, C. A. de la, Catálogo bibliográfico y biográfico del teatro antiguo español, desde sus orígenes hasta mediados del siglo XVIII, Madrid, Rivadeneyra, 1860.

Bergman, H. E., «Calderón en Sevilla: apuntes bibliográficos», in Estudios sobre el Siglo de Oro en homenaje a Raymond R. MacCurdy, ed. A. González, T. Holzapfel and A. Rodríguez, Albuquerque / Madrid, University of New Mexico / Cátedra, 1983, pp. 125-133.

Calderón de la Barca, P., Quarta parte de comedias, Madrid, Joseph Fernández de Buendía, 1672.

Catalina García, J., Ensayo de una tipografía complutense, Madrid, Manuel Tello, 1889.

Cotarelo y Mori, E., "Catálogo descriptivo de la gran colección de "Comedias escogidas" que consta de cuarenta y ocho volúmenes, impresos de 1652 a 1704», Boletín de la Real Academia Española, 18, 1931, pp. 232-280, 418-468, 585-636; 19, 1932, pp. 161-218.

Cruickshank, D. W., «Towards an Atlas of Italic Types Used in Spain, 15281700", in The Iberian Book and its Readers: Essays for Ian Michael, Bulletin of Spanish Studies, 81, 2004, pp. 973-1010.

Cueva, J. de la, Primera parte de las comedias y tragedias, Sevilla, Juan de León, 1588.

Dreyfus, J. (ed.), Type Specimen Facsimiles, London, Bowes and Bowes, Bodley Head, 1963-1972, 2 vols.

Gregg, K. C., An Index to the Spanish Theatre Collection in the London Library, Charlottesville, Biblioteca Siglo de Oro, 1984.

Juliá Martínez, E., "Aportaciones bibliográficas: comedias raras existentes en la Biblioteca Provincial de Toledo», Boletín de la Real Academia Española, 19, 1932, pp. 566-583; 20, 1933, pp. 252-270.

MacCurdy, R. R., Francisco de Rojas Zorrilla: Bibliografía crítica, Cuadernos Bibliográficos, 18, Madrid, CSIC, 1965.

Moll, J., «Diez años sin licencias para imprimir comedias y novelas en los reinos de Castilla: 1625-1634», Boletín de la Real Academia Española, 54, 1974, pp. 97-103.

Paredes, A.V. de, Institución y origen del arte de la imprenta (Madrid, 1680), ed. J. Moll, Madrid, El Crotalón, 1984.

Profeti, M. G., «Un enigma bibliografico: la Parte VI de Comedias Nuevas Escogidas", Annali della Facoltà di Economia e Commercio in Verona. Serie I. Università degli Studi di Padova, 7, 1976-1978, pp. 3-18.

- La collezione Diferentes autores, Kassel, Reichenberger, 1988.

Restori, A., Saggi di bibliografia teatrale spaguola, Geneva, Olschki, 1927. 
Rico, F., El texto del «Quijote»: preliminares a una ecdótica del Siglo de Oro, Valladolid, CECE / Universidad de Valladolid, 2005.

StARK, E., Die Sammlung spanischer comedias in der Universitätsbibliothek Freiburg, Kassel, Reichenberger, 2003, 2 vols.

TimonedA, J. de, Turiana, Valencia, s. e., 1564-1565.

Vega, L. de, El peregrino en su patria, ed. J. B. Avalle-Arce, Madrid, Castalia, 1973.

Vervliet, H. D. L. (ed.), The Type Specimen of the Vatican Press 1628, Amsterdam, Menno Hertzberger, 1967.

Vindel, F., Escudos y marcas, Barcelona, Orbis, 1942.

Wilson, E. M., y Cruickshank, D. W., Samuel Pepys's Spanish Plays, London, The Bibliographical Society, 1980. 


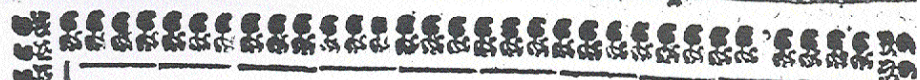

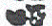 \\ (2) \\ ents

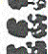

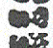 \\ (1) \\ $P$ \\ S E X T A
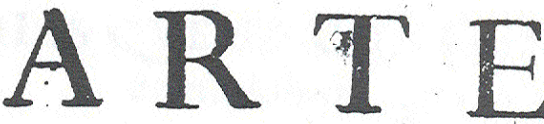 \\ D E \\ C O M E D I A S \\ ESCOGIDAS, \\ DE LOS MEjORES INGENIOS \\ D $\mathbf{E}$ \\ E S P A N A.

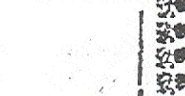 \\ tan

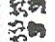 \\ . \\ CON LICENCIA, \\ En Zaragoça, Por los herederos de Pedro \\ Ianaja y Lamarca, Impreffores del. \\ Reyno de Aragon,y dela Vniver- fidad, Año 1653.

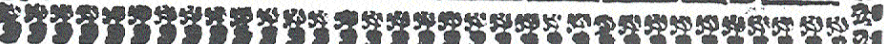

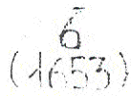

1 Title-page of Sexta parte, Zaragoza, 1653: Österreichische

Nationalbibliothek, Vienna, *38.V.10(6). 
VENGARSE CONEYEGO, Y AGVA:

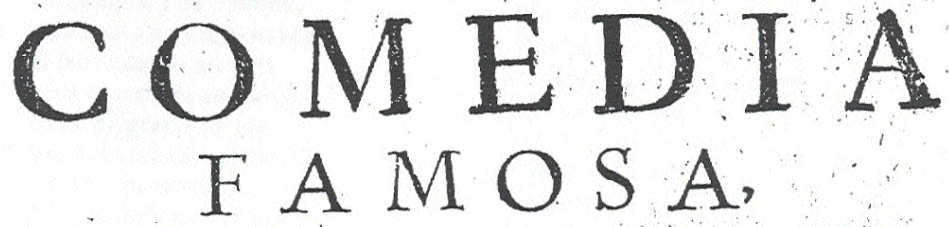

DE DON PEDRO CALDERON.

Hablan en ella las perfonas figuientest

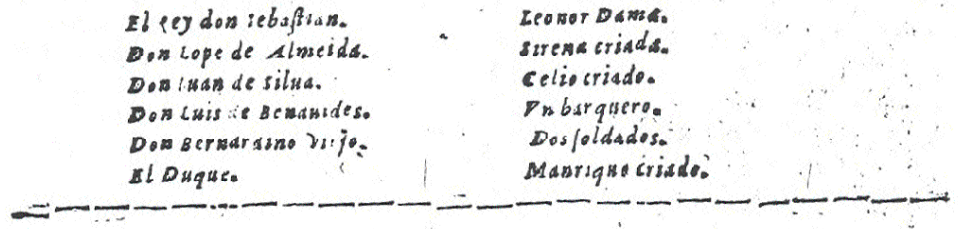

I O R N DA PRIMEA.

sabe el pey don tebapian, don Lope de abmeida, shanrigut, gentede arow pa-

ñamis 0 : 4 .

y a noeftar ocupado

ea la guerra q́en Africa ho intentados

fuera vuetio padrioo.

d. Lop. Otravez,gran féror.os è pedido efta licencia, y otra aucistersido porbien mi calamiento,

mas yoque fiempiea tanta luz atento viuo en vuc ftro lembläte yëgo a daros cuenta de micleccion, y a luplicaros que en vaętra g'acia pacda colgarlasarmas, y que Marceceda a amorla gloria, ciuando en paz reciba en ver de aito lanrel, fagrada cirva. Yo os he fexuido y folamante elpur? ctta merced por galardon folir.ro, puescon efta lisencia venturúa oifaldrè a recejir mi amada efpora.

द्र: Yoeflimo vueftro gulto i vĩu auméto

d. Lop. Eterno dure : ffe lo urcl diuino, que tu: lienes corona.

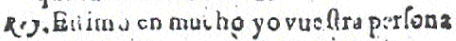
Vajt cl (e) s acimpañamirnie.

Man.Contéto, cllàs d. cop. Míal lupicra la dicha, y li gloria mia; difsimul. I lu ditgria, feize yo ti fu.tiera volar oy. nan.A! viento igualas:

d op. Pucuaproucchiqu: cl viento cs purzoloclemirito; dierame clam : r r fus alas, voiàra abralado y cicgo, pucs quich al vientole tntrega, alas de vienco aeecga,

2 Calderón, Vengarse con fuego y agua: Österreichische Nationalbibliothek, Vienna, ${ }^{\star} 38 . V .10(6)^{12}$. 


\section{S E X T A}

P A R T E

D E

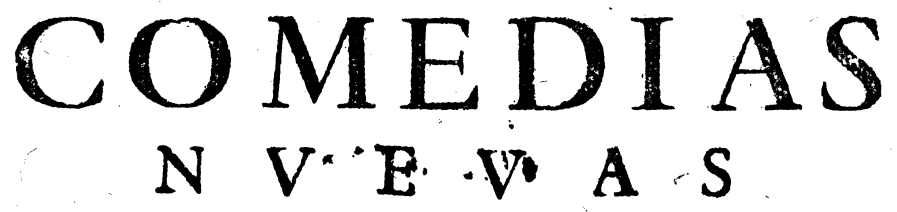

ESCOGIDAS DE LOS MEjORES

-

I N G E N I O S.

3

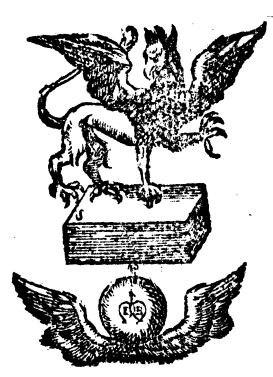

Con licencia, En Zaragaza, Por los Herederos de Pedro Lanaja, Impreffores del Reyno de ARAGON, Año de 1654 . $\alpha$ cofta de Roberto Duport, Mercader de Libros.

3 Title-page of Sexta parte, Zaragoza, 1654: The Bodleian Library, University of Oxford, Arch S III.21. 


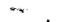 \\ PROGNE, Y FILOMENA. \\ COMEDIA FAMOSA}

\section{DE DON FRANCISCO DE ROjAS.}

\section{Perfonas que hablan en ella}

\author{
Progne. \\ Filomena. \\ Pasdion fu padre. \\ Rey Tereo.
}

Sale Filomema llorando, y Hipolito. Ziip. Uexa el llanto Filomena, que fi es aliuio,es rigor, que por templarte vindolor, me caules a mi vna pena.

Losojos tuyos ierena, no los quiera tu piedad a plaudir con vanidad de ci losen tus defvelos, qui pa; v r que fon ciclos, les fobra la t mpetad. Nobiend ftiladoexales, aljofar de mas valor. fi el lianto es feñal de amor, noderrames las leinales.

Comunicame tus males, fea el dolor repartido al pefo que fue fentido, y ficon fuego veloz yere tupena â tu voz, y ratu voz a mi ollo. Quandoa los cjos preficres tanto dolor reprimido, lloras, porque me has querido, ôllotas, porque me quie res? Que es cundicion de mugeres no er conftantes infico, yo pues que a tus rayos mueto, var pregunto, y mil veces
Hipolito.

Iuanete lacayo primero.

Chilindron lacayo jegundo. Aurelio viejo, Gouernador de Tracia.

lloras, porque me aborreces, ó porque?

Fil. Porque re quiero.

Como,di, puedes dudar

lo que en mi llegas a Ver, quicn llorò de aborrecer? y quien nollora de amar? Tu folpecha he de culpar; y que propongas meefpanto tant a duda dolor tanto en quien llora, y quien fufpita, por que el odio arguye ira, y el amor fupcne llanto.

Hip. Aunque creertc es preciro por lo que arguycondo eftàs, fuele aborrecerfe mas aquello que antes fe quifo. Sirva de exemplo ûte auifo lo contrario pues hi hallado del amor difciplinado, que fuele fermas querido aquel que antes fue admitido, q.e aquel que folo fue amado.

Fil No creastan grane errer, que nof apofenta fiento birnel aborrecimicnto, adonde vinò $\mathrm{el}$ amor. Si aunes laceniz actor, fraquil fuigo cs inuno:tal, A

4 Francisco de Rojas, Progne y Filomena: The Bodleian Library, University of Oxford, Arch S III.214. 


\section{LOS TRABAIOS DE IOB. \\ 85. \\ COMEDIA FAMOSA}

\section{A NVEVA DEL DOCTOR Felipe Godinez.}

Hablan en ella las perfonas figuientes.

$\begin{array}{lll}\text { Iob. } & \text { Efrongraciofo, } & \text { Celfs. } \\ \text { Elifar: } & \text { Dos Angeles. } & \text { Canan. } \\ \text { Sofux: } & \text { Dina. } & \text { Demonio. } \\ \text { Baidar: } & \text { Aftra. } & \text { Losbijos de Iob: } \\ & & \text { Laufo: }\end{array}$

IORNADA PRIMERA.

SalenI $o b$, Dina, Elifar, Sofar, Baldar Sof. Yolojuro. Bal.Y yo prometo? y acompañamiento, $y$ mufica. que aun en los ay res velozes

Eli. Da Iob a tus tres amigos, mi amiftad en voz publiquen ran igualmente conformes los viuientes moradores. los braços, que a marchar tccan. Tob. Porentados de Idumca, B.al. Ya clarines, $y$ tambores que en las vezinas Regiones h an intimado efperanças de Edon, y Arabiz os embidian a nueftros tres coraçones Egypeios Emperadores. de la vitoria. Sof.Y los ecos, Iuttos fois, de los tres fio, que al parche herido refponden, aunque el aiiento os prouoque; el fon al nactal repiten. que a tanta guerra osimpeien

Din.Iob, que es mi efpofo, yos oye legitimos pundonores. defea que $\in$ Ra amift ad fe conferue tan inmouil, que ni el ticmapo la cancele, ni la fortuna la borre,

Eli. Que puede borrar el tiempo; fi con buriles de bronce de nueftros pechos tenemos prefentes obligaciones, tan efcritas, tan vnidas, que quando el tiempo las borre? ferà impolsible faltar Que aunque clvalor es cl timbre? que tanto il uftra a los nobles; el temor de Dios es mas, que efte es blafon de blafones. Que bien parece un gran heroe, tenicndo fis laz por norte; quandoel gran Dios quele zige fujeta afectos, y acciones. Figurad va y pogrifo, que con relinchos ferozes; la firmeza de los montes? ecos de claria fonoro, toda la campaña rotape.

5 Felipe Godínez, Los trabajos de Job: The Bodleian Library, University of Oxford, Arch S III.21 ${ }^{5}$. 


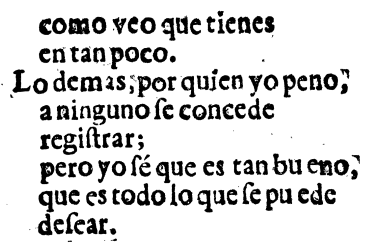

\section{F I N.}

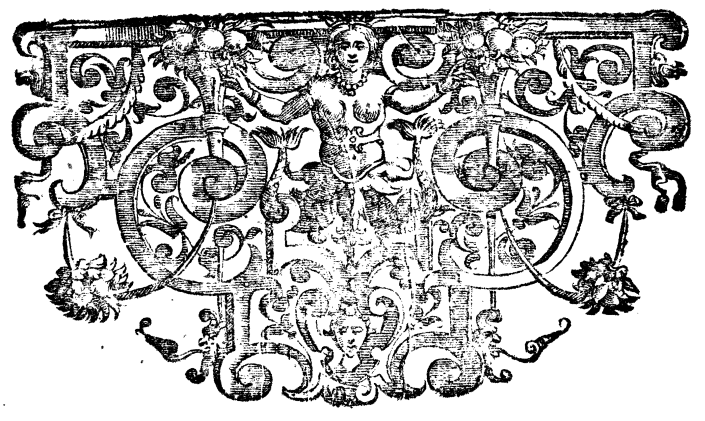

6 Tailpiece of Jerónimo Cáncer, «Pintura a una dama», in Tres Ingenios, $A$ vn tiempo rey y vasallo: The Bodleian Library, University of Oxford, Arch $\Sigma$ III. $21^{10}$. 